\title{
Road to Extermination in Uganda
}

\author{
Eric L. Edroma
}

Uganda's national parks are littered with elephant carcasses, poachers' camps and meat-drying racks, and poachers are better armed and equipped than the guards. And the slaughter continues. Dr Edroma, who is Director of the Uganda Institute of Ecology, lists the steps that must be taken if the present disastrous situation is not to deteriorate to the point where Uganda's wildlife is effectively exterminated.

Uganda possesses a diversity of habitats and consequently a wide variety of floral and faunal species. This variety, together with the large herds of some animals, has probably been the main attraction for tourists, and elephant, rhino, buffalo, lion, giraffe all bring in tourists. The tragedy now is that the very large animals are on the verge of elimination.

Thousands of elephants have been killed in the seven years since 1973, and the once healthy and quite considerable population is now highly endangered. In 1973 there were a little over 30,000 elephants in the country; by 1976 the number was 6000 , and by November 19784000 . A census completed in April 1980 shows no more than 2000 in the whole of Uganda: 150 in Rwenzori National Park, 1400 in Kabalega Falls National Park, 125 in Kidepo Valley National Park, and at the very most 300 in all the Game and Forest Reserves. And as I write the numbers are probably still lower, since the poaching continues unabated. Uganda's national parks are littered with elephant carcasses, poachers' camps and meat-drying racks. The term 'genocide' applies to the elephant slaughter in Uganda. The picture in the field is horrifying, pathetic and sad.

The causes for all this mess are easy to find. The breakdown in law and order, the declining economy, the get-rich-quick drive, the spread of human settlements, the ease of access to elephant range, and the inability of the park and game staff to control the situation have all combined to create the anarchy.

Wildlife overexploited by poachers in such a senseless manner becomes a non-renewable natural resource and species become extinct. The quagga in South Africa became extinct through relentless hunting by white settlers; whales have been overhunted almost to extinction; the tigers in Asia have been overhunted and are now rare. In Uganda, the white rhino is believed to be extinct this year, and black rhino, mountain gorilla, the spotted cats, and crocodiles, among others, are highly endangered. There are some 100 mountain gorilla in Bwindi Impenetrable Forest in south-west Uganda and a dozen in the Mountain Gorilla Game Reserve adjoining Rwanda.

The future of Uganda's wildlife is an issue of grave concern. Ugandans should consider themselves fortunate to be so richly endowed with wildlife. Unfortunately this very pride is much abused by those who regard wildlife as a nuisance or as a source for quick cash returns.

The elephant is victimised because of its tusks, which for the animal are a tool for digging and breaking trees and a weapon for fighting. The white rhino has been eliminated for its horn, and lion, cheetah, leopard, crocodile, mountain gorilla, and zebra face extinction because of their skins. Others - 
buffalo, antelopes, etc. - have been slaughtered for meat.

Uganda's neighbours and other African countries have realised that wildlife must be protected. In September 1973 Kenya banned elephant hunting and ivory dealings, and in 1977 extended the ban to include all other game. In 1973 Zaire banned elephant hunting. In the mid-1970s Tanzania imposed a ban on hunting game, and many other African countries have reacted strongly to the elephant massacre. Uganda banned elephant hunting in December 1975 and imposed a total hunting ban in September 1979, but the recent IUCN African elephant survey shows that elephant depletion is at its highest in Uganda. Obviously these Ugandan laws remain on paper only.

Banning and law-making are not enough; they merely stop the licensed hunting. Poaching, the illegal hunting, continues. The authorities responsible for wildlife conservation should address themselves to the questions, how can we ensure that the laws governing wildlife protection are actually implemented? How can we stop poaching?

\section{What Must be Done}

I believe that the Ugandan Government has the means to bring the menace of poaching in the country to an end, and I have made the following proposals:

1. All firearms should be withdrawn completely from the public and stored for safety. There are too many firearms in the hands of the public, and poachers are better equipped with automatic weapons than the anti-poaching forces;

2. Sale of firearms and ammunition to the public should be banned;

3. Chiefs and all in authority should be empowered to arrest anyone poaching or dealing in wildlife products. Sale of wildlife meat should be banned;

4. Poaching should be considered a more serious crime than ever before and more stringent steps taken in dealing with poachers;

5. The Government should invest heavily in the conservation field. The parks' vehicles, firearms, and other equipment were looted during the 1979 liberation war. Rehabilitation and reconstruction of the national parks should be a priority so that tourism can be opened to generate the much-needed foreign currency. The parks should be provided immediately with badly needed Land Rovers, guns, ammunition, uniforms, field equipment, petrol, and more staff, with regular payment of salaries;

6. The public should be educated on the value of wildlife in the socio-economic life of the country. More coverage in the mass media should be devoted to wildlife conservation and education. The Government should step up support for the activities of the Wildlife Clubs of Uganda;

7. Uganda should become a signatory of the Organisation of African Unity Convention for the Conservation of Nature, and of the Convention for International Trade in Endangered Species (CITES) and any other treaties for wildlife conservation.

The wildlife in Uganda is not for the Ugandans alone to benefit from; it is for the enjoyment and benefit of all mankind. Governments, international agencies and other bodies all over the world should assist Uganda to put right the machinery for proper administration and enforcing law and order, and in controlling poaching in the country.

Dr Eric L. Edroma, Uganda Institute of Ecology, Box 22 Lake Katwe, Uganda. 